\title{
The meaning of the Ceprotan tradition in bersih desa for the people of Sekar village
}

\author{
Laras Andita Yuningtyas *, Sigit Pranawa, Yuhastina Yuhastina \\ Universitas Sebelas Maret. \\ Jl. Ir. Sutami No.36, Kentingan, Jebres, Surakarta, Jawa Tengah 57126, Indonesia. \\ sutur.andhita@gmail.com \\ * Corresponding Author
}

\section{ARTICLE INFO}

\section{Article History}

Received:

4 November 2019;

Revised:

19 December 2019;

Accepted:

24 December 2020

\section{Keywords}

Ceprotan tradition; Tradition ceremony; Symbolic meaning;

\begin{abstract}
The purifying tradition carried out by the Sekar Village community is always accompanied by a traditional ceremony called Ceprotan. This Ceprotan traditional ceremony only exists in Sekar Village. Its implementation load with folklore values that the local people believe. This study aimed to know the meaning of the Ceprotan tradition for the people of Desa Sekar. This research used a qualitative method with a phenomenological approach. The intake of informants was done through the purposive sampling technique. Data obtained using both secondary and polymer data. Data collection techniques used were interviews, observation, and documentation. To ensure the validity of the data, the researcher used source triangulation techniques on the data obtained. The data were then analyzed with cultural interpretation techniques or the "thick description" approach by Clifford Geertz to interpret the symbol systems of cultural meaning in a deep painting. This study's findings were that the village's purifying tradition accompanied by the Ceprotan traditional ceremony carried out by the Sekar Village community, especially Krajan Lor and Krajan Kidul Hamlets, was done as an expression of gratitude, hope, and prayer to God Almighty for good things. Based on cultural practitioners' symbolic activities that appeared and were interpreted, this tradition was also carried out as a form of appreciation and reminder to Sekar Village's ancestors, which until now is believed by the community as Danyang who consider influencing the survival of the local people. This belief contains in the folklore of the origin of Sekar Village. It continues to maintain as a form of refinement of the customs and culture of Sekar Village.
\end{abstract}

This is an open access article under the CC-BY-SA license.

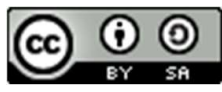

\section{INTRODUCTION}

Javanese people or Javanese people are known as a tribe that is polite, subtle, slightly closed and has a frank nature (pleasantries) because it avoids conflict (Bratawidjaja, 2000). Javanese people are also known to uphold values that maintain the balance of life order, manifested in a time-honored tradition that continues to cultivate. Van Peursen (1988) translates tradition as the process of inheritance or forwarding norms, customs, rules, and property. In Java Island itself, the majority of people who live in the countryside always maintain local traditions. These traditions are kept because they are considered meaningful and have functions in various aspects and phases of people's lives. Kastolani and Yusof (2016) explained that tradition is part of people's culture. According to Prayogi and Danial (2016), culture in society will continue to develop in accordance with the changing times. 
According to Khan, Iqbal, and Gazzaz (2012), the development of culture is related to the media of the time in a community.

A picture of Javanese society that is thick and identical with the tradition inherent in its culture is one of the regions in Java Island, namely in the Province of East Java, precisely in the city of Pacitan. This city is known as a tourist town with many beaches and underground caves, so it has a slogan or nickname "City 1001 Goa". However, in terms of its socio-cultural life, in reality, the people of Pacitan natives of Java also have and still carry out various local traditions. Among them, the tradition of Kethek Ogleng dance art from Tokawi Village, Nawangan District. The oldest puppet art tradition in the archipelago is Wayang Beber from Gedompol Village, Donorojo District. Then there is also a familiar tradition in Java land commonly called bersih desa. This tradition is carried out in Cemeng Village accompanied by Adu Kloporitual, and in Sekar Village attended by Ceprotan ceremony.

Subalidinata explained that a clean village is a form of village congratulations carried out by villagers in Java after the harvest season as a form of gratitude and is believed to have meaning and function for life's safety (Endraswara, 2006). The village's clean tradition has different designations, procedures, times, and implementation places in each community that carries it out. The assignments for the pure rule of villages in various regions that carry them out include Rasulan, Memetri Desa, Gumbregan, or Sedekah Desa. As also explained by Endraswara (2006), a clean town has the essence of a phenomenon to seek life salvation. It contains spiritual art that mystical manifestations of Kejawen in the village clean manifest in various activities of tradition and art. Therefore, in the pure implementation of the town, accompanied by multiple activities, including the division of Ingkung, making offerings, puppet performances, dances, and or Tayuban.

Like the clean tradition of Sekar village, one of 12 towns in Donorojo Subdistrict, Pacitan Regency. Clean village in Sekar Village accompanies by a traditional ceremony commonly called Ceprotan. In general, the village's pure implementation in the form of simple thanksgiving activities by the community concerned. However, the clean town that is routinely carried out by Sekar villagers every year is accompanied by a series of traditional ceremonies containing spiritual, sacred, and festive art that attracts many visitors. The traditional Ceprotan ceremony held every Longkang or Sela month on the Javanese calendar has folklore values from the legend of Ki Godheg and Dewi Sekar Taji's meeting, which became the origin story of Sekar Village and ceprotan tradition itself (Sunjata, 2010).

Most Javanese people carry out the bersih desa tradition, but the ceprotan traditional ceremony is only done in Sekar Village. As has been recognized by the Permanent Delegation of the Republic of Indonesia to UNESCO that Ceprotan is an Intangible Cultural Heritage that is the only one in the area and determined by the Representative Office of the Republic of Indonesia (KWRI) UNESCO in 2016 with the category of ceremonies or rites, with registration number 2016006758 (Kemendikbud.go.id). This tradition's uniqueness is highlighted by various parties, including visitors from various regions, the press, and media crews who come to witness, capture, and expose the tradition in this series of clean events in this village. Thus, making the routine schedule of Sekar Village more festive every year and potentially as the development of tourist destinations. Therefore, maintaining this traditional activity well by the community is an important thing that needs to be studied. In the era of human civilization development increasingly modern, the unique and distinctive tradition in Sekar Village is not lost eroded by the era.

According to Rohani, Novianty, and Firmansyah (2018), the government's role in preserving the nation's culture is also very important. However, the government has a strategic role in the efforts to preserve the culture of the area in the water. The government must implement policies that lead to efforts to preserve national culture. One of the government policies that deserve to be supported is regional cultures' appearance in every major national event. All of that must be done as an effort to introduce to the younger generation that the culture displayed it is the legacy of his ancestors. According to Tuan and Navrud (2008), culture is an important community heritage to be preserved. According to Luo and Chen (2016) cultural heritage can be preserved in modern society's life. According to Vecco (2010) cultural heritage has meaning and is important to preserve.

Preservation of local culture for a community is important, especially in the era of globalization. According to Triwardani and Rochayanti (2014), the process of globalization also 
provides space for the exchange of cultural goods (consumer goods) and the acceleration of the cultural constellation that leads to the emergence of cultural industries. In this context, cultural uniformity or homogenization becomes interchangeable commodities. At the same time, however, the cultural localization movement emerged as a unique cultural response to a global force of uniform character, massif, and westernization bias. The series of social symptoms that arise from globalization once again mandate decision-makers to immediately change policy direction in the management of cultural resources. According to Asri (2016), the management of cultural resources can be done with legal protection.

Conveyed in Sunjata (2010), traditional traditions or rituals as symbols, rich in information because the signs of condensation (change of form) demonstrated can take the form of solidified behavior. Traditional patterns are a source of unwritten cultural details. However, they have essential meaning for the supporting community and outsiders interested in understanding it. Therefore, based on the background exposure above, the researchers conducted a study titled "The meaning of the Ceprotan tradition in bersih desa for the people of Sekar village" (Phenomenological Study on Sekar Village Community, Donorojo District, Pacitan Regency). In this study, researchers analyzed with viewpoint the theory of Symbolic. Interpretivism by Clifford Geertz. where culture defines as a system of symbols, it contains historically transmitted patterns of meaning. Culture can be understood by translating and interpreting the meaning of existing symbols, giving an idea of the world and cultural actors' feelings.

\section{METHOD}

This research location is in Sekar Village, Donorojo Sub-District, Pacitan Regency. The research was conducted from February to the end of July 2019. This research uses a qualitative method with a phenomenological approach. Researchers chose a phenomenological approach concerning the goal to achieve in this study, exploring a tradition's meaning. With phenomenology, researchers seek to interact, equalize the level of thinking, and capture what is hidden in the "heads" of cultural actors. Then perform interpretations to find the meaning of the various symbolic activities that appear.

Informant retrieval was done by purposive sampling technique. In this study, the informants were village heads, community leaders, a gatekeeper who were gatekeepers people, and residents of Sekar Village. Data collection techniques with observations, interviews, and documentation. To test the validity of the data, researchers used source triangulation. The data are then analyzed using cultural interpretation analysis techniques or thick description, according to Clifford Geertz, to provide in-depth paintings of the traditions studied and interpret the cultural systems that exist in them.

\section{FINDINGS AND DISCCUSIONS}

Findings

The agricultural sector is the main cornerstone of Sekar village's economy. Based on monography data of Sekar Village in 2017, as many as 2,498 out of 3,527 Sekar villagers have a livelihood as farmers, both cultivating their agricultural land and becoming farm workers. Irrigation of agricultural land obtained from irrigation channels, water sources Sekar village, and rainfed system. Some other residents who do not farm meet their economic needs by becoming industrial workers, hunting h buildings, employees (civil servants and private), craftsmen, traders, the home industry, etc. According to Sertoglu, Ugural, and Bekun (2017), the agricultural sector affects a community's economy. Researchers in the agricultural sector's contribution to essential communities or countries are carried out.

As a native of Java, Javanese people's kinship is still thickly attached to Sekar villagers' lives. Although their settlements are not dense because there are still many farms and fields between one house and the other, their solidarity is very well established and proven by the preservation of Javanese cultures that reflect social solidarity such as activities jagong bayi, tilikan, sambatan, layat, rewangan, banca'an, nyumbang, and so on carried out by Sekar villagers voluntarily. There are also

Volume 7, No. 2, September 2020 
institutions or organizations formed by the community and village government to support the community's various activities and needs, including PKK, taruna coral, farmer groups, customary institutions, and religious organizations.

All Sekar villagers adhere to Islam. However, Sekar villagers also believe and practice habits outside the teachings of Islam. These activities include giving offerings and doing obong-obong (burning frankincense) in certain places and times, doing kendurian or banca'an accompanied by yasinan, and soon. This is because Sekar Village people are still influenced by the belief of Kejawen Islam, which is a syncretization of Islamic teachings with pre-Hindu elements Hindu-Buddhist teachings. Moreover, before knowing religion, Javanese people adhered to the beliefs of animism and dynamism, where they worshiped the spirits or spirits of ancestors.

Like the Javanese people in general, Sekar Village people also carry out the village's clean tradition, a hereditary tradition of Javanese people concerning agriculture and produce. However, bersih desa in Sekar Village has its characteristics because it is accompanied by Ceprotan culture that only exists in Sekar Village. This tradition is very popular among Sekar Village and surrounding areas because it is a unique tradition, and every year is held festively to bring in many visitors. Ceprotan tradition is a series of clean traditional processions of the village, which at its peak is carried out throwing young coconuts at each other commonly called degan or embut-embutan carried out by hundreds of young men divided into two camps, namely those from Krajan Lor Hamlet and Krajan Kidul Village Sekar, throwing stones at people carrying Panggang in the middle of the field where Ceprotan was held.

\section{History of Sekar and Ceprotan Villages}

Ceprotan tradition is closely related to the history of Babat Alas Sekar village. In Sekar Village's legend, there are two plays, namely Ki Godheg and Dewi Sekar Taji, who are believed to be the ancestors or elders of Sekar Village. The two characters are told to travel and meet in a forest (Sekar Village). At that time, Dewi Sekar Taji felt thirsty and asked Ki Godheg for drinking water. However, because there is no water source in the forest, Ki Godheg takes young coconuts from coastal areas. As her gratitude, because Sekar Taji is a great royal princess, she poured coconut water in the forest land until there appeared a strong and clear spring. He then named the source by the name of Sumber Sekar. He advised that someday if many people have inhabited the place, he left a will to Ki Godheg to carry out the traditional ceremony using degan or cengkir (young coconut). Ki Godheg then performed Babat Alas and built the shaman, which is now called Sekar Village. Ki Godheg always advises the citizens and their descendants to continue to carry out Ceprotan on Monday Kliwon Sela or Longkang in the Javanese calendar.

To maintain the historical story of the trust of the people of Sekar Village put a ballet that tells Ki Godheg and Dewi Sekar Taji's meeting in the procession of Ceprotan traditional ceremony. The dance was performed before the peak of the Ceprotan event. This aims to bring down the historical story to every Sekar villager and maintain its sustainability. Besides, Sumber Sekar with a large banyan tree nearby, which is believed to be the passage where Ki Godheg and Dewi Sekar Taji met, is now a must. Likewise, Ki Godheg's tomb in Sekar Village cemetery is also sacred. At certain times, especially before the implementation of Ceprotan, both places were offered by the gatekeecat by doing obong-obong (burning incense) in the place while reciting mantras or prayers that are a hope for the welfare of Sekar villagers.

\section{Ceprotan Tradition Implementation Process}

In a series of village cleanup events in Sekar Village, various social activities are arranged, including mass service activities, healthy walks, volleyball tournaments between hamlets, multiple competitions, and entertainment events. These various activities held to revitalize the annual agenda of Sekar Village and expect to build social solidarity among Sekar Village residents. Thus, residents interact from various hamlets in a clean village atmosphere and share performances as entertainment and recreation. Towards the village cleanup implementation, multiple preparations were made by the committee that had been prepared by the village management. In addition to that, the practice assists residents. They are starting from compiling the rundown of the event, preparing various performances and performers that will be displayed in the series of events, collecting bluluk or 
cengkir, which is the main means of the Ceprotan procession, preparing various offerings, preparing the field for the Ceprotan procession area to take place, making an entertainment stage, installing Umbul- pennant, and so forth.

Sekar village consists of 10 hamlets, namely Krajan Lor, Krajan Kidul, Klumpit, Golo, Sobo, Tritis, Karet, Tukul, Ngrijang, and Gondang Manis hamlets. Most of the residents who participate in preparing and managing the village cleanup and Ceprotan events' sustainability are Krajan Lor and Krajan Kidul hamlets residents. The core hamlets concerning the implementation of this Ceprotan. Participants or penceprot in the Ceprotan procession were also young men and men from the two hamlets who were then separated into two camps. However, in various social activities involving the participation of residents from all Sekar Village. And in terms of preparation and other matters, the committee is also open to Sekar Village residents' support and involvement. Approaching the day of implementing the Ceprotan tradition, various symbolic activities related to these traditional rituals and ceremonies began to appear. Ceprotan is always held on Monday Kliwon or Kliwon Sunday in Longkang month. On the night before the next day, Ceprotan was held, the caretaker and several residents performed nyekar or visited Ki Godheg's grave. The locksmith then cleaned the grave, made crackers or burned incense, read prayers, then sprinkled flowers on the tomb. In the morning, the caretaker also visited Sumber Sekar, brought Panjang Ilang (offering container) containing Sajen for Danyang, which was then placed under a large tree that grew near the source. After that, the caretaker did a chatterbox and read a prayer. Obong-obong activities in places that are considered sacred are intended as a way to inform and ask permission from the ancestors that the village and Ceprotan will be cleaned up and to ask for the smoothness and the grant of the citizens of Sekar Village through this tradition.

After coming from Lepen or Sumber Sekar, the caretaker then goes home to prepare various ubo rampe to implement the Ceprotan traditional ritual. The offerings or ubo rampe include tumpeng lulut, tumpeng tulak, vegetables, grilled, puppets, and so on. According to Sekar Village residents' residents, these various it must provide for the smooth running of the Ceprotan traditional procession. There are particular meanings that these objects can be said to be symbolic tools in the Ceprotan tradition ritual. After completing the preparation, all the ubo rampe and offerings take to the PKK orphanage located in the village hall.

The ritual procession objects collect in a particular room where the caretaker will also perform obong-obong in the room before the village cleanup procession continues. The salvation follows by residents of Krajan Lor and Krajan Kidul hamlets. They came to the village hall with some of the necessities for salvation. Each head of the family is required to collect one Ingkung and Jadah chicken. Several other residents at the back of the PKK Home prepared Ingkung sauce and several other dishes for the salvation event. Inside the PKK Panti, residents also help each other cutup chickens and jadah, arrange the salvation snacks on teak leaves for several family heads present, and then distribute them back to the residents. After the caretaker finished doing obong-obong near the offerings, the salvation event began with remarks by the village head and the village cleaning committee's chairperson. The reading of prayer follows them. Then the salvation snacks were distributed back to the residents to take home with the hope that all families and residents who eat it will bless with the clean village salvation that has been carried out.

After the celebration hold, a series of village clean-up events continued with the appearance of various entertainment for the Sekar Village community and visitors from outside the area who had started arriving. The entertainment show display on an entertainment stage established not far from the village hall and the field where the Ceprotan procession is located. The entertainment featured included a marching band by children from SD Negeri 1 Sekar, Reog Ponorogo and Jathilan, dances, Kothekan Lesung or Rontek, and Beksan, which were almost entirely performed by Sekar Village residents themselves. This event also explores the potential and creativity of citizens in terms of traditional arts and entertainment. Residents and traders used the crowds of visitors arriving from various regions to sell and sell different kinds of merchandise and starting from conventional food, snacks, drinks, toys, clothes, etc. Not only that, but there are also service traders who hold playground stalls for children. These various economic potentials are one of the benefits obtained from the Ceprotan event. After a late afternoon and different entertainment, performances have been performed. It is time for the Ceprotan procession to begin. They were starting with a ballet's 
performance, which tells of the meeting between Ki Godheg and Dewi Sekar Taji as the Sekar and Ceprotan villages' origin. The colossal dance performs by dancers who were residents of Sekar Village. After the ballet's performance, penceprot participants, who were young men and boys from Krajan Lor and Krajan Kidul hamlets dressed all in black, entered the Ceprotan arena carrying bamboo baskets full of cloves. After each penceprot from the two hamlets was ready in their respective camps, a procession of community leaders who brought gunungan, offerings and $u b o$ rampe was followed. The caretaker led the march to the middle of the Ceprotan arena, between the two penceprot camps.

Since noon, the Ceprotan arena has been given incense-burning stoves at various angles. The smell of incense has spread throughout the field. Plus, the situation that was getting closer to evening made the atmosphere even more mystical. However, the closer to the Ceprotan event's peak, the crowd was crowded with the audience area. Indeed, since a long time ago, the procession and the culmination of this ritual must always be carried out when it was late afternoon or so-called wayah surup. The residents and caretakers believe that if the time is not right, it has not yet entered surup time, then the invitation means the unseen spirits have not arrived and will be disappointed. Likewise, if it is too late or passing surup it is also not suitable for the implementation of Ceprotan. Towards surup the caretaker performed obong-cones in the middle of the field and read the prayers. After that, the caretaker stood up, carrying bake and cangak. The gamelan was sung; all the Ceprotan participants danced with enthusiasm while shouting. Each penceprot is ready to grasp and brandish the cengkir to throw.

The time came. Someone grabbed banggang and cangak, the caretaker, then quickly broke the jug filled with water; at that moment, hundreds of penceprot from both camps shouted boisterously and threw cengkir at their best. The person who stole the bake was the target of cengkir's throwing. However, he still danced in the middle of the field even though bluluk's throws repeatedly attacked his body until it was soaked. Approximately 20 minutes, thousands of cengkir floated in the air with the rhythm of the gamelan increasingly timid plus the screams of enthusiasm from the penceprot. Locksmiths, committees, and security guards monitor the road's orderliness in Ceprotan and ensure the spectators are safe.

Meanwhile, many residents, the press, photographers, and spectators captured the peak moment of Ceprotan. Some are just watching and enjoying the unique and unique traditional rituals. After the bluluk-bluluk in the basket ran out, the penceprot from the two camps then came out of the barrier and joined in dancing together in the middle of the field to celebrate the end of the Ceprotan peak, which they had just done. As Sekar Village residents, all Ceprotan participants feel relieved to have carried out their obligations that are part of their culture and traditions. After enough, the participants direct to leave the Ceprotan arena in an orderly manner by the committee and security officers. Likewise, residents and visitors, some dispersed, some waited because at night they would watch a wayang kulit or which is a Javanese story doll performance all night long, which was also held as part of a series of village clean-up events.

\section{The Meaning of Ubi Rampe Ceprotan}

What is meant by Cengkir is young coconut, which use to throw each other between the two camps at the top of the Ceprotan procession. To not cause injury, thousands of degan's grains picked from coconut trees in Sekar Village are skinned first and are left to rest or dry in the sun until they soften. When they are thrown and fall or hit other objects, they will burst, releasing water called nyeprot. Its belief that whoever expose to "ceprotan" Cengkir will get a blessing. Cengkir is also often interpreted as an abbreviation of kenceng ingikir, which means human reason or mind that is used seriously.

Bake and chop Grilled, and Cangak is whole grilled chicken. Each stuck into a bamboo piece in a different position. Chickens' belief to be a symbol of prosperity. Simultaneously, the number of two tails symbolizes the story that two characters, Ki Godheg and Panji Asmoro Bangun, disagree with the level of Babat Alas, Sekar Village. In this Ceprotan procession, it hopes that the dispute will not happen to the residents. This bake and cangak in the Ceprotan procession are classified or taken away by someone from the caretaker's hand. It indicates that Ceprotan has reached its peak, and the Ceprotan participants can start throwing bluluk at each other. 
Long Ilang In general, the offering container is called bokor. It is made of brass. However, in this Ceprotan procession, the offering container is called Panjang Ilang. It is made of a series of yellow coconut leaves. Since this object is related to the offerings that will hand over to the ancestral spirits or Danyang, according to the caretaker's belief and the residents of Panjang Ilang it will not be easy to form and assemble if the construction is not done on Kliwon Day.

Tumpeng lulut and krecek tumpeng lulut are sticky rice cooked and kneaded into jadah then formed into round plates and several other shapes. Tumpeng lulut made from glutinous rice, has a philosophy that the people of Sekar Village are expected to have a close family relationship. In Javanese, it is called rinaketan, sticky and difficult to separate like the texture of sticky rice or jadah. Tumpeng lulut is placed in a container called tampah and surrounded by a crunchy food made from sticky rice, also called krecek. Krecek belief to be a symbol of kerapan, which means rapping or absorbing and destroying diseases and all dangers.

Tumpeng tulak is a gunungan tumpeng made from polo pendem (tubers), which is boiled and crushed by hand. After forming a gunungan, it is given a circular line called the paningset belt, yellow with turmeric and black with charcoal. Tumpeng tulak has a meaning as a repellent for 6 reinforcements, thare is gambir, gantal, kinang (tobacco), and suruh (betel leaf) are the ingredients for nginang. It is an activity of chewing tobacco and other elements commonly practiced by Javanese women in ancient times. Offerings provide for the purpose or meaning of being a meal for daughters or women's ancestral spirits. These materials are placed in Panjang Ilang. Vegetables several types of vegetables (long beans, moringa leaves, and bean sprouts) grow in Sekar Village. There are used as offerings in the Ceprotan tradition as a sign and hope that all kinds of plants planted in the rice fields, fields, and yards of Sekar Village residents can flourish. And become a source of livelihood for the residents of Sekar Village.

Benceng, urang, and yuyu Several animals that live in Sumber Seding consist of shrimp, and crap, can live in two realms (water and land or wet and dry). The provision of these animals' belief to have a philosophy that being human must adapt to various situations and conditions of life. Gedhang sepet and bolah telon one type of banana belief to be a plant that lived in the wilderness for a long time before becoming Sekar Village. It is steamed and then stuck with an object which is made of thread and a four-forked pole. It is used and believed by the caretaker as a medium or means of communication with unseen spirits from the four directions, present as invitations to the Ceprotan procession. Bolah telon which is made from thread, has a philosophy of Allah's singular expression. That humans have the power to pray and try, but the one who answers is God.

Sticky tape is usually made from cassava or glutinous rice, then fermented with yeast and wrapped in banana leaves. Since most Sekar Village residents are farmers, it believes that using the ketan tape symbol will grant residents hopes of repelling plant pests. As the name implies, the term is for removing plant pests. Wayang two shadow puppets depicting a pair of lovebirds; Janoko and Sembodro figures complement the offerings ceprotan procession as a symbol of sakjodo. It contains the hope that the relationship between residents in Sekar Village has compatibility, harmony, and happiness and the meaning contained in the term match.

\section{Discussion}

With the presentation of this study's results, it was found that there was an understanding that all forms of activities in the implementation of bersih desa and Ceprotan traditional ceremonies were cultures passed down from generation to generation from ancestors or ancestors. In agreement with what Clifford Geertz expressed, being human is being an individual. As humans, we become individuals under the direction of cultural patterns, historically created meaning systems with which we give form, structure, subject, and direction to our lives (Geertz, 1992b). At first, bersih desa event and the Ceprotan traditional ritual base on a legend or folklore that tells the Sekar Village's origin. At the same time, this story contains the values of the conventional inheritance, which until now have been internalized and maintained by the residents of Sekar Village, namely the Ceprotan traditional ritual. The main characters in this legend, namely Dewi Sekar Taji and Ki Godheg, have become legendary figures known by the community in Sekar Village. This kind of appreciation to ancestors or when they become spirits is called Danyang according to what Geertz wrote: 
Danyang is considered the spirit of historical figures who have died: the founder of the village in which they live, the first to clear the land. Every town usually has a Danyang, he is usually buried near the village center after death, and his grave then becomes punden. He continues to pay attention to the welfare of his village (Geertz, 1989).

It is not only enough to remember the legend. Sekar Village residents have also internalized the values that have been considered noble from generation to generation from every story or historical history of their village's origin. The clean town and Ceprotan traditional rituals manifest many values or meanings that are manifested in various forms or forms of culture, from activities to physical objects or artifacts used in the implementation of this series of traditions. In a series of processions, a character (caretaker) is obliged to perform mystical activities, namely burning incense or incense in certain places such as ancestral graves and historic sites in a water source under a large banyan tree (Lewisohn, 1997). Reciting mantras or prayers to ask for the ancestors' blessing, carry out their wishes, and carry out obligations covered by a hereditary cultural tradition. Residents also prepare offerings to ancestors or Danyang and unseen invitations during the traditional ceremony procession. Among them are Degan or young coconut, which is believed to be the forerunner to the water source of Sekar Village, Kinang as a treat for Danyang or unseen invitations, animals from village water sources that have certain philosophies, vegetables with certain meanings and hopes, various tumpeng reinforcements repellent, various other offerings that have been previously described. Each resident also carries out a joint salvation activity, and all of them voluntarily carry multiple needs as a condition for fulfilling the clean needs of the village for their village. When the Ceprotan procession took place, all the people involved in the procession were immersed in a sacred atmosphere, which led them to realize cultural patterns and fulfill these symbols with meanings that only belonged to them as humans or residents of Sekar Village. As Geertz argues that:

Moods caused by sacred symbols, at different times and places, from ecstasy to deep sadness, respectively, from self-confidence to self-pity, from careless playfulness to mild lethargy to say nothing of the erogenous power of so many world myths and rites. There is nothing more than a single motivation that people might call piety. There is one type of mood that people might call devoted (Geertz, 1992a).

Based on the data findings regarding the activities or activities and euphoria of Sekar Village residents in implementing bersih desa and Ceprotan traditional ceremonies, an overview of the meaning of the entire series of activities is obtained. The fact that the people of Sekar Village, especially Krajan Lor Hamlet and Krajan Kidul Hamlet, internalize the historical values contained in the folklore that develop in their communities, to give rise to a distinctive culture, create belief in the rites that are maintained, and interpret them with symbols that contain hopes sublime for goodness and survival. According to Geertz's opinion, through cultural patterns, namely a series of regular, meaningful characters, humans give meaning to their experiences (Geertz, 1992b). According to Rathje (2009), people interpret culture as part of the experience. According to Arbay, and Laksmono (2020), the experience relates to events and the history of the community. According to Hussaini (2020), history can build a society's identity. According to Meuleman, Bekhuis, Lubbers, and Scheepers (2013), the culture of a society or nation can strengthen the nationalism of nefara citizens, especially the younger generation. Similar to Setyawan and Saddhono (2018), Cannigia (2015), and Prahastiwi (2014), they have Ceprotan performing art performed the sendratari (dramatic dancing art) telling the story of Ki Godeg and Dewi Sekar journies with developing the Sekar Village.

\section{CONCLUSION}

Based on research on the meaning of the Ceprotan tradition in village cleaning for Sekar Village people. It is concluded that Sekar Village people interpret bersih desa activities coupled with Ceprotan customs to show gratitude to the Almighty for the blessings, fortune, and safety they have to obtain. Furthermore, as a means of praying prayers and high hopes for the survival of Sekar Village residents. The implementation of the Ceprotan traditional ceremony, which only exists in Sekar 
Village, is fully interpreted by the community, especially from Krajan Lor and Krajan Kidul hamlets, as a form of appreciation, reminder, and offerings to the ancestors of Sekar Village. The fact is that the people of Sekar Village believe in the existence of ancestral spirits or Danyang, which still influences the village community's survival. Thus, traditions are carried out according to wills, which are believed to have originated from the ancestors' advice to create harmony in cultural patterns and community life. The Sekar Village community enthusiastically welcomes and implements the clean village tradition, coupled with the Ceprotan custom as a form of obligation that must be carried out to perfect their customs and culture. In each of these activities, residents prepare and carry out symbolic activities full of noble meanings and hope for a smooth life. Historically, the activities have been passed down from generation to generation through the legend or folklore values developed in Sekar Village regarding origin Sekar Village. Cultural inheritance occurs in the form of behavior patterns that have symbolic meanings shared and maintained and maintained by the cultural owner, namely Sekar Village residents.

\section{REFERENCES}

Arbay, E. A., \& Laksmono, B. S. (2020). Tangible and intangible cultural heritage in support to postwar Biak tourism. Technium Social Sciences Journal, 14(1), 727-734. doi: https://doi.org/10.47577/tssj.v14i1.2040

Asri, D. P. B. (2016). Perlindungan dan pengelolaan budaya lokal di kota Yogyakarta. Jurnal Kajian Hukum, 1(1), 1-22. Retrieved from http://www.academia.edu/download/59879480/6-80-1PB20190627-125447-1sp03nh.pdf

Bratawidjaja, T. W. (2000). Upacara Tradisional Masyarakat Jawa. Jakarta: Pustaka Sinar Harapan.

Cannigia, A. B. (2015). Potensi Upacara Adat Ceprotan Sebagai Wisata Minat Khusus Di Kabupaten Pacitan (Unpublished doctoral dissertation). Universitas Gadjah Mada, Indonesia.

Endraswara, S. (2006). Mistisisme dalam seni spiritual bersih desa di kalangan penghayat kepercayaan. Kejawen: Jurnal Kebudayaan Jawa, 1(2), 38-61.

Geertz, C. (1989). Abangan, Santri, Priyayi dalam Masyarakat Jawa. Jakarta: Pustaka Jaya.

Geertz, C. (1992a). Kebudayaan dan Agama. Yogyakarta: Kanisius.

Geertz, C. (1992b). Tafsir Kebudayaan. Yogyakarta: Kanisius.

Hussaini, M. (2020). The historical sources of nationalism in the contemporary China. Technium Social Science Journal, 13, 536-550. Retrieved from https://heinonline.org/HOL/LandingPage?handle=hein.journals/techssj13\&div=48\&id=\&p $\underline{\operatorname{age}}=$

Kastolani, K., \& Yusof, A. (2016). Relasi Islam dan budaya lokal: Studi tentang tradisi Nyadran di Desa Sumogawe Kecamatan Getasan Kabupaten Semarang. Jurnal Kontemplasi, 4(1), 5174. Retrieved from http://ejournal.iaintulungagung.ac.id/index.php/kon/article/download/130/105

Kementerian Pendidikan dan Kebudayaan Republik Indonesia. (2018). Data pokok kebudayaan, profil objek tak benda. Retrieved from https://dapobud.kemendikmud.go.id

Khan, F. R., Iqbal, Z., \& Gazzaz, O. B. (2012). Communication and culture: Reflections on the perspectives of influence. Wulfenia: Journal Klagenfurt, Austria, 19(8), 197-212. Retrieved from https://www.researchgate.net/profile/Fazal_Khan3/publication/253341225_Communicatio $\mathrm{n}$ and culture Reflections on the perspectives of influence Wulfenia Journal_198 197 -212/links/00b7d52678673420bd000000/Communication-and-culture-Reflections-on-theperspectives-of-influence-Wulfenia-Journal-198-197-212.pdf 
Lewisohn, L. (1997). The sacred music of Islam: Samā'in the Persian Sufi tradition. British Journal of Ethnomusicology, 6(1), 1-33. doi: https://doi.org/10.1080/09681229708567259

Luo, J., \& Chen, F. (2016). Preservation of traditional culture in modern society: A case study of China Meishan Cultural Park. International Journal of Sustainable Development and Planning, 11(3), 416-425. Retrieved from https://www.witpress.com/cart/openaccessdownload

Meuleman, R., Bekhuis, H., Lubbers, M., \& Scheepers, P. (2013). Own culture first? Nationalism and the preference for national cultural goods. International Journal of Public Opinion Research, 25(4), 436-458. doi: https://doi.org/10.1093/ijpor/eds024

Prayogi, R \& Danial E. (2016). Pergeseran Nilai-Nilai Budaya Pada Suku Bonai Sebagai Civic Culture Di Kecamatan Bonai Darussalam Kabupaten Rokan Hulu Provinsi Riau. Jurnal Humanika, 23(1): 61-79.

Peursen, V. (1988). Strategi Kebudayaan. Yogyakarta: Kanisius. Rudyansjah, T. (2015). Antropologi Agama. Jakarta: UI Press.

Prahastiwi, E. D. (2014). Nilai Pendidikan Dalam Budaya Ceprotan Masyarakat Desa Sekar Kecamatan Donorojo Kabupaten Pacitan (Doctoral dissertation, Universitas Muhammadiyah Surakarta).

Rathje, S. (2009). The Definition of Culture: An Application-Oriented Overhaul. Interculture Journal, 8(8): 35-58.

Rohani, R., Novianty, F., \& Firmansyah, S. (2018). Analisis upaya melestarikan nilai-nilai budaya pada masyarakat adat Melayu di Kecamatan Sungai Kakap Kabupaten Kubu Raya. Vox Edukasi, 9(2), 271442. doi: https://doi.org/10.31932/ve.v9i2.174

Sertoglu, K., Ugural, S., \& Bekun, F.V. (2017). The contribution of agricultural sector on economic growth of Nigeria. International Journal of Economics and Financial, 7(1), 547-552. Retrieved from https://www.econjournals.com/index.php/ijefi/article/view/3941/pdf

Setyawan, B. W., \& Saddhono, K. (2018). Ceprotan performing art: A traditional folkart based on urband legend. Harmonia: Journal of Arts Research and Education, 18(1), 67-73. doi: https://doi.org/10.15294/harmonia.v18i1.9509

Sunjata, W. P. (2010). Upacara tradisional Ceprotan di Pacitan. Jurnal Patrawidya Seri Penerbitan Sejarah dan Budaya, 11(3), 771-789

Triwardani, R., \& Rochayanti, C. (2014). Implementasi kebijakan desa budaya dalam upaya pelestarian budaya lokal. Reformasi: Jurnal Ilmiah Ilmu Sosial dan Ilmu Politik, 4(2), $102-$ 110. Retrieved from https://45.32.120.76/index.php/reformasi/article/view/56

Tuan, T. H., \& Navrud, S. (2008). Capturing the benefits of preserving cultural heritage. Journal of Cultural Heritage, 9(3), 326-337. doi: https://doi.org/10.1016/j.culher.2008.05.001

Vecco, M. (2010). A definition of cultural heritage: From the tangible to the intangible. Journal of Cultural Heritage, 11(3), 321-324. doi: https://doi.org/10.1016/j.culher.2010.01.006 